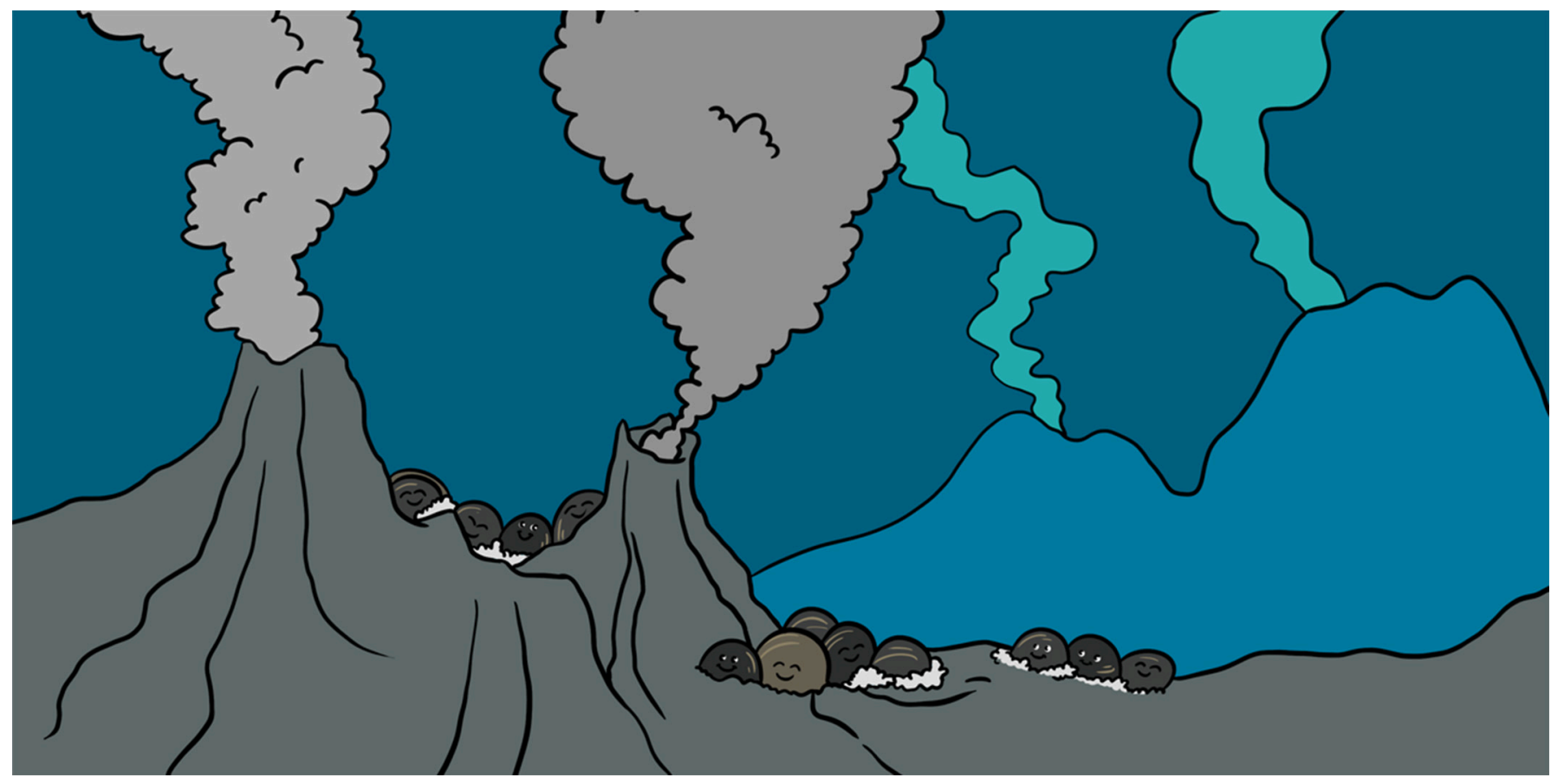

\title{
A MUSSEL'S LIFE AROUND DEEP-SEA HYDROTHERMAL VENTS
}

\author{
Sébastien Duperron ${ }^{1,2 *}$, Sylvie M. Gaudron ${ }^{3,4}$ and Sven R. Laming ${ }^{5,6}$ \\ ${ }^{1}$ Muséum National d'Histoire Naturelle-UMR7245 (MNHN CNRS) Mécanismes de Communication et Adaptation des \\ Micro-organismes (MCAM), Paris, France \\ ${ }^{2}$ Institut Universitaire de France, Paris, France \\ ${ }^{3}$ UMR 8187 Laboratoire d'Océanologie et Géosciences (Univ. Lille, CNRS, Univ. Côte d'Opale), Wimereux, France \\ ${ }^{4}$ Sorbonne Université, UFR927 and UFR918, Paris, France \\ ${ }^{5}$ Sorbonne Université, UMR 7208 BOREA (CNRS), Paris, France \\ ${ }^{6}$ UMR6197 Laboratoire de Microbiologie des Environnements Extrêmes and Laboratoire Environnement Profond, Ifremer (UBO, \\ CNRS) CS 10070, Plouzané, France
}

\section{YOUNG REVIEWER:}

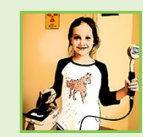

MAREN

AGE: 10
Hydrothermal vents are places where seawater exits cracks in the sea floor, having been super-heated and enriched with metals and minerals deep in the underlying bedrock. They are an example of an ecosystem based on chemosynthesis, where life is sustained by energy from chemicals rather than energy from sunlight. The discovery of an abundance of life around deep-sea hydrothermal vents emitting hot and toxic fluids demonstrated that animals and other organisms could thrive in the dark, cold and high-pressure deep oceans. Mussels are among the most studied animals found near hydrothermal vents. Scientists discovered that mussels rely on a close, living relationship-a "symbiosis"-with bacteria for their nutrition. In this symbiosis, bacteria use chemicals from the 
PHOTOSYNTHESIS

Process that allows plants and algae to harness the energy in sunlight for growth and reproduction.

PRIMARY

PRODUCTION

The amount of organic carbon (converted from inorganic carbon either by photosynthesis or chemosynthesis) produced by those organisms that do not eat other organisms (termed "primary producers" e.g., plants, algae, bacteria). The energy from these primary producers is repeatedly transferred to "consumers" (anything that eats another form of life) through a complex feeding network.

\section{ORGANIC CARBON}

A collective term for carbon-based compounds that are essential for building and maintaining living cells. These compounds are the "building blocks" of all life. hydrothermal fluid and seawater to produce organic compounds, while the mussels provide the bacteria with essential compounds and protection. The mussel life cycle is uniquely adapted to finding and colonizing their unusual habitat and then finding suitable symbiotic bacteria, almost immediately. Despite its remoteness, the deep sea is already under threat. Although there is still much work to be done, research into mussels and other animals that have evolved similar symbioses has revealed not only their beauty, but also their fragility.

Sunlight provides plants and algae with energy for growth and reproduction. This process of photosynthesis sustains much of life on Earth (including humans), and is responsible for most of Earth's primary production, the amount of organic carbon produced by photosynthetic organisms (normally, but see below) in a given habitat area and time. Sunlight rarely penetrates deeper than $200 \mathrm{~m}$ in oceanic waters, beneath which photosynthesis cannot occur. Instead, animals depend upon nutrients that sink down as debris. The deep sea is also cold $\left(2-4^{\circ} \mathrm{C}\right)$ and under tremendous pressure from the weight of overlying water. All this makes for a vast, inhospitable environment. In fact, until quite recently, scientists assumed life could not survive in the deep. In the 1960s, technical advances in deep-sea exploration (e.g., submersibles, towed cameras) revealed scarcely populated soft-sediment plains, with bizarre-looking fish, sponges, sea anemones, sea stars, and sea cucumbers. However, our perception of the deep sea changed fundamentally in 1977 when scientists discovered numerous giant tubeworms and seashells crowded around rock chimneys emitting searing-hot fluids (exceeding $300^{\circ} \mathrm{C}$ ), 2,500 m deep, near the Galápagos islands (Figure 1). The discovery of these hydrothermal vents demonstrated that animals were thriving without sunlight under some of the most extreme conditions described on Earth.

\section{HYDROTHERMAL VENTS AND COLD SEEPS ARE DEEP-SEA OASES OF LIFE}

Deep-ocean hydrothermal vents occur where there is intense volcanic activity. Seawater permeates rock, heats up and becomes enriched with substances from the rock, like metals, sulfide, dihydrogen, and methane. Mineral-rich chimneys, around which hydrothermal-vent animals live, then form when these heated fluids exit the seafloor (Figure 1). During the 1980s, scientists realized that these habitats supported an unusual type of primary production, fueled not by sunlight and photosynthesis, but by energy from reactions between chemicals found in the hydrothermal fluid, like sulfide, and the oxygen present in seawater. Amazingly, some basic, single-celled microorganisms can use this energy to build the parts of their one 
Figure 1

(A) Drawing of a hydrothermal vent site by a school girl. Giant tubeworms and mussels are shown in the drawing.

(Anthonine

Gaudron--Lefebvre).

(B) A type of hydrothermal vent called a black smoker, on the mid-Atlantic Ridge (@) Ifremer, cruise BioBaz, Lallier [5]). (C) A smaller vent emitting slightly cooler fluid, surrounded by patches of Bathymodiolus mussels, through which crawls a large Chaceon crab (@) Ifremer, cruise BioBaz, Lallier [5]).

\section{HYDROTHERMAL VENT}

A place where, due to intense underwater volcanic activity, super-heated fluids form mineral-rich chimneys as they exit the seafloor. These fluids contain reducing compounds that can be used

for chemosynthesis.

\section{CHEMOSYNTHESIS}

Process where chemically reducing compounds (sulfur, methane) provide bacteria and some other microorganisms with energy for growth and reproduction.

\section{SYMBIOSIS}

\section{A close relationship} between different species living together, in some cases a symbiosis is mutually beneficial. The largest species is called the host, the smaller species is (or are) the symbiont(s).
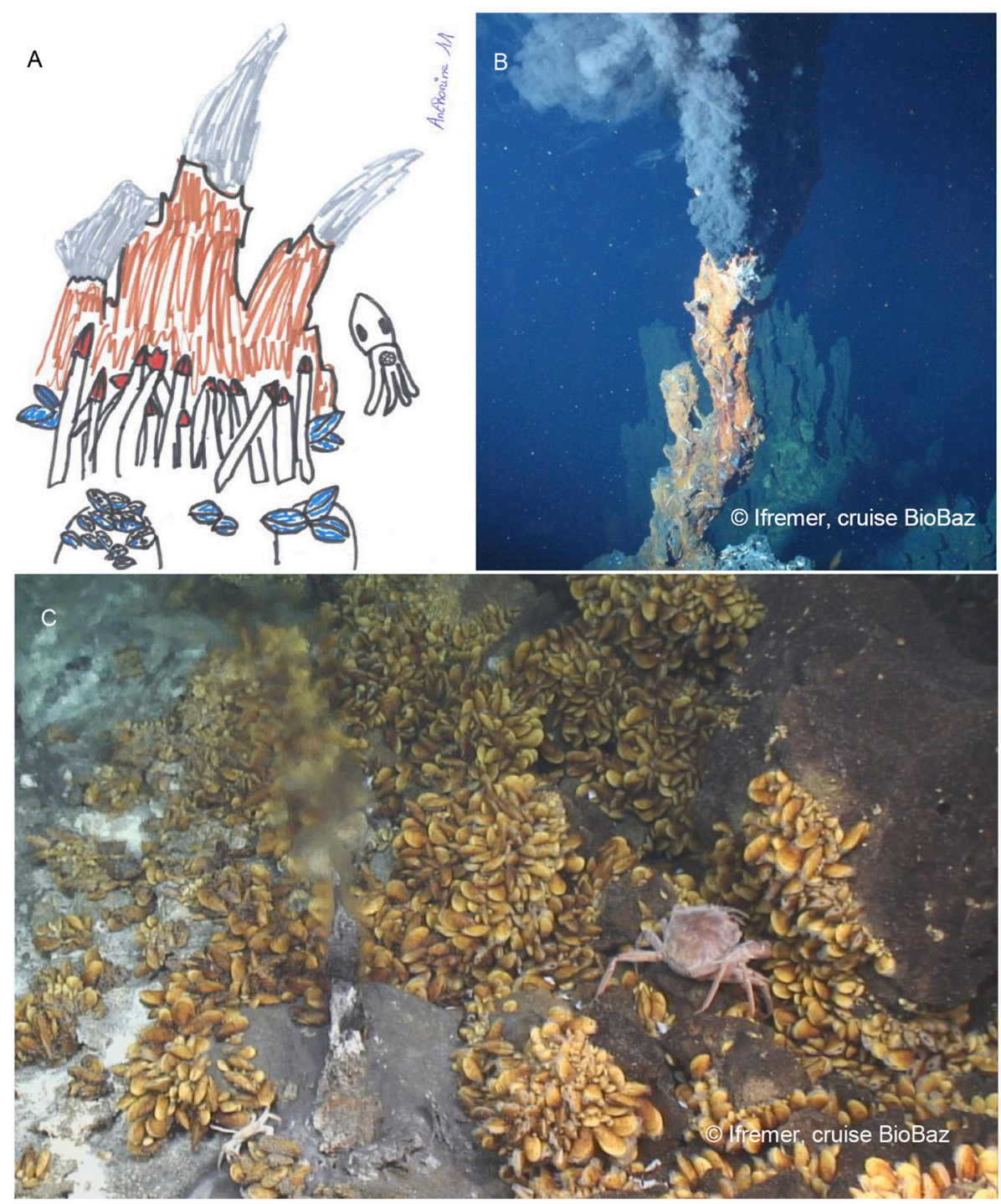

Figure 1

cell. Hydrothermal vents provided the first evidence that this process, called chemosynthesis, could sustain so much life in otherwise desert-like surroundings.

But what about the larger animals that live in these environments? How do they get the energy they need to survive? Well, many of these animals acquire their energy by maintaining close relationships with chemosynthetic bacteria. This type of relationship, where two different organisms live together closely is called symbiosis. In chemosynthetic symbioses, both organisms involved are believed to benefit from the relationship. The larger organism is called the host and the smaller organism, the bacterium in this case, is called the symbiont. The bacteria live in specialized organs within their hosts, and their primary production provides the host with energy. In exchange, the host furnishes its bacteria with shelter and essential compounds. Examples of animal at hydrothermal vents that harness symbioses include giant 
Figure 2

Adult specimens of Bathymodiolus heckerae, a large mussel found at cold seeps in the deep Gulf of Mexico, near Florida. Adult mussels, depending on the species, may have shell lengths between $2 \mathrm{~mm}$ and $40 \mathrm{~cm}$.

\section{COLD SEEP}

Habitat typically dominated by soft sediments where the decay of plant and animal remains buried under the sediment results in the production of fluids rich in reducing compounds that can be used for chemosynthesis, either within the sediment or at locations on the sea floor where the compounds seep out.

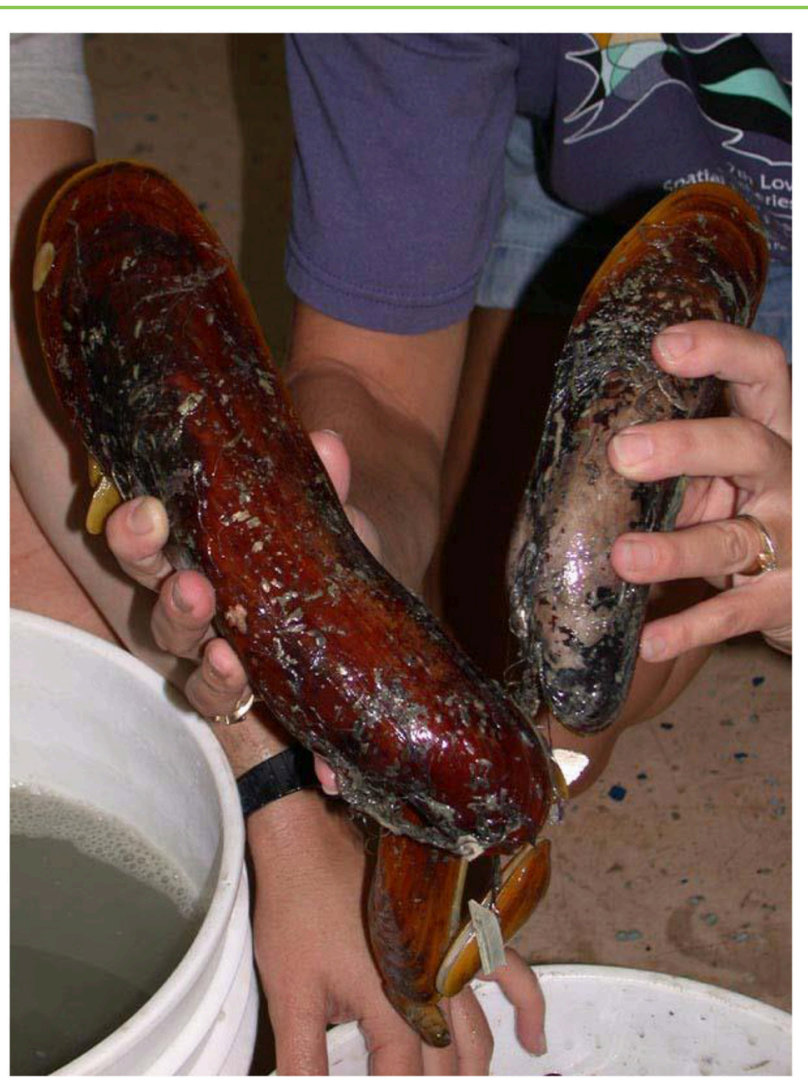

Figure 2

tubeworms and bivalve clams (Figures 1, 2). In 1984, similar symbioses were described in animals living around fluids seeping from seafloor sediments rich in sulfide and methane, found in the Gulf of Mexico. These areas are different from hydrothermal vents and are called cold seeps, because the temperature of the seeping fluids is close to that of bottom seawater. Cold seeps are caused by the decay of plant and animal matter that has accumulated on the sea floor, buried under sediment. Other sulfide- and methane-rich deep-sea habitats (Figure 3), such as decaying wood falls or large carcasses, sustain similar but smaller-sized organisms. Symbioses allow all these organisms to thrive in the deep sea.

\section{DEEP-SEA MUSSELS REVEAL HOW ANIMALS ADAPT TO HYDROTHERMAL VENTS AND COLD SEEPS}

Among the most remarkable of these animals that can survive in the deep sea are bathymodioline mussels. These mussels are in the same family as edible mussels, but the Bathymodiolinae have become specialized for living in deep-sea environments over the last 60 million years. Various species are found worldwide, with shell lengths from $2 \mathrm{~mm}$ (the size of a sesame seed) to $40 \mathrm{~cm}$ (the size of a laptop screen) (Figure 2). Bathymodioline mussels can carpet hundreds of square meters of seafloor (Figure 1), often as a large component of 
Figure 3

Life cycle of bathymodioline mussels in the deep sea. (1) Oval center-habitats include a fluid larval environment (upper ocean part) and a settled post-larval life in a chemosynthetic environment (lower seabed part, example habitats are depicted); (2) Oval perimeter, widening arrows-visual interpretation of developmental stages during mussel life cycle until adulthood (not to scale); (3) Multi-colored ring-energy sources used during life cycle from an early non-feeding stage-via several feeding stages - to an adult symbiotic stage established sometime after bacterial colonization of juvenile mussel host; (4)

Outermost

region-important developmental events related to specific life-cycle stages (in blue) and the bacterial colonization process (in red).

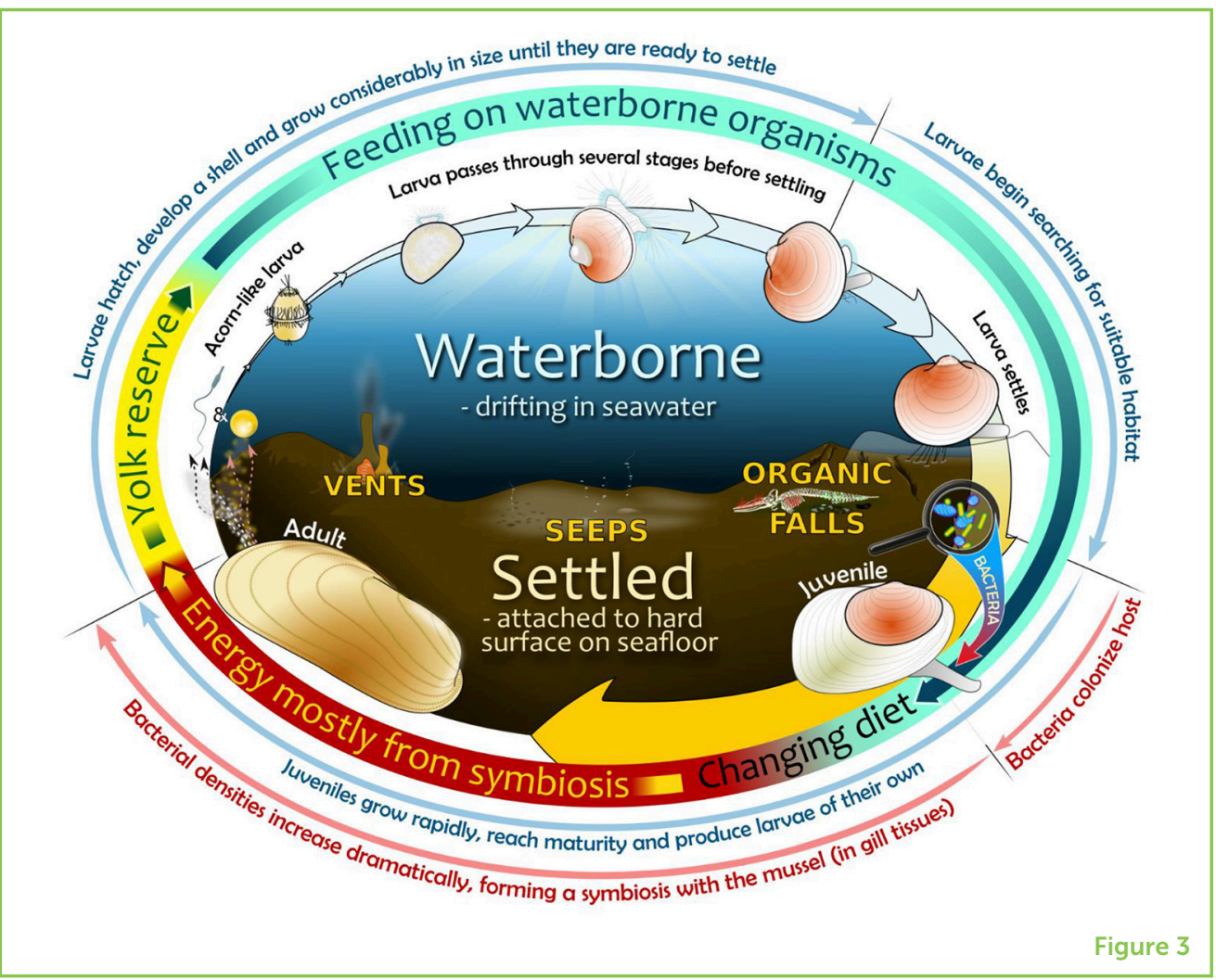

hydrothermal-vent and cold-seep communities, yet they generally are not found anywhere else in the ocean. Scientists have been researching these mussels for about 35 years, to figure out how they survive in these extreme ecosystems. Despite the difficulty of studying an animal that lives in the deep sea, scientists have identified many aspects of the mussels' lifestyle that make them adapted to deep-sea life.

\section{ADULT MUSSELS HAVE PLENTY OF BACTERIAL SYMBIONTS IN THEIR GILLS}

Deep-sea mussels have enormous gills, with surfaces up to 20 times larger than that of similarly sized edible mussels! Approximately 1,000 billion symbiotic bacteria live in and on the gills of these mussels. This is equivalent to the number of bacteria found in $1 \mathrm{~kg}$ of deep-sea sediment or 1,000 liters of seawater, and it is more than 100 times the number of people found on Earth!

In most mussel species, this high number of bacteria is made up of only one or two different types. The first type of bacteria, called a sulfur-oxidizer, consumes sulfide from the vent fluids and oxygen from the surrounding seawater, to produce organic carbon, which the host can use as an energy source. The second, called a methanotroph, uses methane $\left(\mathrm{CH}_{4}\right)$ for both energy and carbon. One scientist demonstrated that mussels with methanotrophs in their gills 
could grow on methane alone [1]! Another research group found that the numbers of each type of bacteria can change, depending on how much sulfur and methane are present in the environment [2]. This helps the mussels adapt to changing environments in the deep sea.

Deep-sea mussels can also feed by filtering organisms out of seawater using their gills, like other mussels do, but deep-sea mussels actually get most of their nutrition from their symbionts, either by using the molecules produced by the bacteria, by digesting the symbiotic bacteria themselves, or both.

\section{MUSSELS HAVE ADAPTED TO FIND HYDROTHERMAL VENTS AND COLD SEEPS AND TO ACQUIRE THEIR SYMBIONTS}

In addition to their extraordinary symbionts, the life cycle of deep-sea mussels is astounding. In order to survive as a species, the larva must first grow and develop, find a suitable habitat on which to settle, mature as adults and ultimately produce their own larvae, all without dying along the way! However, during the earlier stages of their life cycle, mussel larvae are highly vulnerable to being eaten or transported away from suitable habitat completely. Mussels overcome these challenges by producing larvae in the thousands! Our research group was interested in discovering how and when symbionts are acquired during the mussel's life cycle, so we collected mussels at various life stages to investigate this (Figure 3). By dissecting and examining these specimens, we found that the mussels do not yet possess symbionts at the moment they arrive on the seafloor, instead acquiring the symbionts shortly after settling on suitable habitat and becoming juveniles. This means that mussels do not inherit symbionts from their parents and do not rely on symbionts for food during their larval life, instead feeding on other organisms in the water. Scientists believe that deep-sea mussels go through several waterborne larval stages like their shallow water relatives, before attaining their characteristic adult form. Having initially survived on an egg yolk provided by its mother, the earliest feeding stage of a mussel's life is a simple acorn-shaped larva with no shell, bearing little resemblance to an adult (Figure 3). However, the shell soon begins to form and the tiny larva undergoes several complex changes while continuing to feed and grow as it drifts in ocean currents. Hydrothermal vents and cold seeps in the deep ocean present particular challenges as they are highly scattered and separated by vast distances, so the chances of a single settling larva reaching a suitable habitat are particularly low. Deep-sea mussels appear to compensate for this by producing larvae that can drift over unusually large distances and for long periods of time to reach a suitable habitat. In one study, computer simulations revealed that a limited number of mussel larvae released in the Gulf of Mexico from known seep location could travel for more than 4,500 km (over 2,800 miles) over a 13 months period, resulting in larvae reaching locations 
off the coast of Nova Scotia and far into the Mid-Atlantic [3]! This suggests that the larvae of some mussel species can colonize very distant vents and seeps. Studies have shown that mussel larvae are very efficient at finding a suitable habitat. How they do this remains a mystery and an important, future area of study.

It is only after arriving and settling on suitable habitat, that symbionts are acquired from the adult environment, or from neighboring adult mussels (Figure 3). Bacteria first establish on all of the juvenile mussel's skin-like surfaces. However, as the mussel grows and matures into an adult, only gill-associated bacteria persist and increase dramatically in number.

\section{ARE MUSSELS (AND OTHER ANIMALS) READY TO FACE THE THREATS TO LIFE IN THE DEEP SEA?}

Despite its remoteness, the deep sea is already under threat from human activity. Cold seeps provide oil, fueling our cars, and hydrothermal vents are threatened because they contain highly valuable mineral resources, such as lithium for our batteries [4]. Understanding how animals have adapted to these ecosystems is important in order to understand the impact that human activities will have, and whether the animals in these habitats can recover from any damage to the habitats caused by human activities. The deep sea is challenging to reach and experimentation on its many and varied inhabitants is difficult. It is only through the dedication of deep-sea scientists and the use of submersibles, underwater robots, and specialized equipment that we are beginning to understand the basics of deep-sea biology. The deep sea is one of the last true wildernesses on Earth. Hydrothermal vents were discovered 8 years after humans first set foot on the moon. This is why we understand so little, and it emphasizes why we must protect the deep sea, from which come some of the most beautiful and bizarre organisms known to science.

\section{ORIGINAL SOURCE ARTICLE}

Laming, S. R., Gaudron, S. M., and Duperron, S. 2018. Life-cycle ecology of deep-sea chemosymbiotic mussels: a review. Front. Mar. Sci. 5:282. doi: 10.3389/fmars.2018.00282

\section{REFERENCES}

1. Childress, J. J., Fisher, C. R., Brooks, J. M., Kennicutt, M. C. II, Bidigare, R., and Anderson, A. E. 1986. A methanotrophic marine molluscan (Bivalvia, Mytilidae) symbiosis: mussels fueled by gas. Science 233:1306-8.

doi: 10.1126/science.233.4770.1306 
2. Szafranski, K. M., Piquet, B., Shillito, B., Lallier, F. H., and Duperron, S. 2015. Relative abundances of methane- and sulfur-oxidizing symbionts in gills of the deep-sea hydrothermal vent mussel Bathymodiolus azoricus under pressure. Deep Sea Res. Part I Oceanogr. Res. Pap. 101:7-13.

doi: 10.1016/j.dsr.2015.03.003

3. Young, C. M., He, R., Emlet, R. B., Li, Y., Qian, H., Arellano, S. M., et al. 2012. Dispersal of deep-sea larvae from the intra-american seas: simulations of trajectories using Ocean models. Integr. Comp. Biol. 52:483-96. doi: $10.1093 / \mathrm{icb} / \mathrm{ics} 090$

4. Van Dover, C. L. 2014. Impacts of anthropogenic disturbances at deep-sea hydrothermal vent ecosystems: a review. Mar. Environ. Res. 102:59-72. doi: 10.1016/j.marenvres.2014.03.008

5. Lallier, F. 2013. BIOBAZ 2013 Cruise, Pourquoi pas? R/V. doi: 10.17600/13030030

SUBMITTED: 15 November 2018; ACCEPTED: 13 May 2019; PUBLISHED ONLINE: 29 May 2019.

EDITED BY: Mahasweta Saha, Plymouth Marine Laboratory, United Kingdom

CITATION: Duperron S, Gaudron SM and Laming SR (2019)

A Mussel's Life Around Deep-Sea Hydrothermal Vents. Front. Young Minds 7:76. doi: 10.3389/frym.2019.00076

CONFLICT OF INTEREST STATEMENT: The authors declare that the research was conducted in the absence of any commercial or financial relationships that could be construed as a potential conflict of interest.

COPYRIGHT @ 2019 Duperron, Gaudron and Laming. This is an open-access article distributed under the terms of the Creative Commons Attribution License (CC BY). The use, distribution or reproduction in other forums is permitted, provided the original author(s) and the copyright owner(s) are credited and that the original publication in this journal is cited, in accordance with accepted academic practice. No use, distribution or reproduction is permitted which does not comply with these terms.

\section{YOUNG REVIEWER}

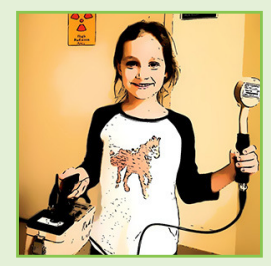

\section{MAREN, AGE: 10}

I am a student who loves to learn, read, and write. I play piano and violin. I like science and math at school, and to read books and watch movies at home.

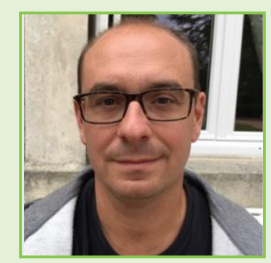

\section{AUTHORS}

\section{SÉBASTIEN DUPERRON}

I am a professor at the French National Museum of Natural History in Paris, France, in the laboratory called Communication Molecules and Adaptation of Microorganisms. I am teaching about microbes, animals, and their interactions, mainly in the marine realm. My research aims at understanding how bacteria and animals establish fruitful 

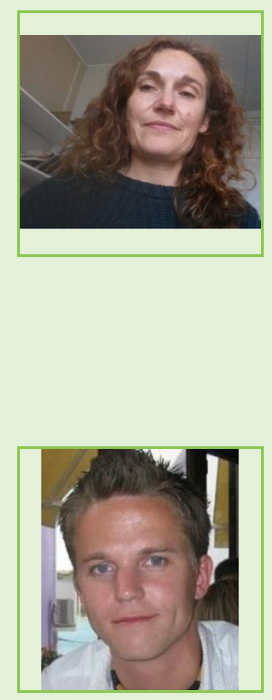

relationships that help each other survive (and eventually thrive) in harsh conditions, such as those encountered in the deep sea or in contaminated environments. *sebastien.duperronamnhn.fr

\section{SYLVIE M. GAUDRON}

I am an associate professor at Sorbonne Université in Paris, France, where I teach animal biology and marine biology and ecology. I do my research in another place in the north of France, in the Laboratory of Oceanology and Geosciences, based at the marine station of Wimereux on the Channel Sea. I have been working on life-history traits of marine invertebrates (reproduction, development, dispersal...) for 20 years, with special interests in bivalves (mussels) and polychaetes (worms) from deep-sea chemosynthetic habitats.

\section{SVEN R. LAMING}

I currently work on the reproductive biology of several deep-sea species at the Universidade de Aveiro (Portugal). However, my work has previously focused on understanding the role of symbionts throughout the life cycle and anatomical development of their hosts in deep-sea organisms, mostly molluscs (mussels and sea-snails). This research involves various techniques, from performing microscopic analyses, dissections, and some mind-blowing 3D scanning techniques, to performing live experiments and looking for clues in host and symbiont DNA. My work has afforded me the opportunity to work in many parts of Europe and present my research worldwide, typically with an excessive use of color and photography! 